\title{
A cDNA Encoding a New Member of the Rat Placental Lactogen Family, PL-I mosaic (PL-Im)
}

\author{
Mitsuko HIROSAWA, Ryuichi MIURA, KwAN-SiK MIN, \\ NAKa HATTORI, Kunio SHIOTA and Tomoya OGAWA \\ Laboratory of Cellular Biochemistry, Veterinary Medical Sciences/Animal Resource Sciences, \\ The University of Tokyo, Tokyo 113, Japan
}

\begin{abstract}
We have isolated a cDNA encoding a novel placental lactogen (PL), PL-I mosaic (PL-Im), by screening the cDNA library in $\lambda Z A P$ of the mid-pregnant (day 12) rat placenta. The cDNA comprised an open reading frame of $687 \mathrm{bp}$ encoding 229 amino acids, in which there were two putative Nglycosylation sites. Northern blot analysis showed that PL-Im mRNA was expressed specifically during mid-pregnancy (days 10 and 12) in the rat placenta. The cDNA was highly homologous with those of other rat PL family members; in particular, the homology among PL-Im, PL-I (mid-pregnancy-specific) and PL-Iv (late-pregnancy-specific) was over 90\%. Interestingly, the nucleotide sequence of PL-Im cDNA was a mosaic of PL-I and PL-Iv and it did not possess its own particular sequence. As the genomic pattern determined using Southern blot analysis of PL-Im was distinct from that of PL-I and PLIv, the encoded area of PL-Im appears to be independent of those of PL-I and PL-Iv on the gene. In the dendrogram of the rat PL family constructed on the basis of the nucleotide sequence homologies, PL-Im was located between PL-Iv and PL-I in the process of molecular evolution. Therefore, PL-Im has a unique cDNA structure and may be a principal factor in the molecular evolution of PLs.
\end{abstract}

Key words: Rat placental lactogen, Placental lactogen I mosaic, cDNA, Cloning.

(Endocrine Journal 41: 387-397, 1994)

THE PLACENTA produces a PRL- or GH-like hormone known as placental lactogen (PL), which is found in several mammals, including the rat [1], mouse [2], cow [3], sheep [4], monkey [5], and human [6]. In the rat, the PL family shows structural homology with PRL. To date, the cDNAs of 6 members of the rat PL family have been cloned: PL-I [7], PL-II [8], PL-Iv [9], PRL-like protein-A (PLP-A) [10], PLP-B [11] and PLP-C [12]. Only PL-I has been found to be a mid-pregnancy-specific PL; all the others were expressed predominantly during late-pregnancy $[1,7]$.

In addition to PL-I, there appear to exist multiple

Received: February 17, 1994

Accepted: March 18, 1994

Correspondence to: Dr. Kunio SHIOTA, Laboratory of Cellular Biochemistry, Veterinary Medical Sciences/Animal Resource Sciences, The University of Tokyo, 1-1-1 Yayoi, Bunkyo-ku, Tokyo, 113, Japan types of molecules with PL activity in the midpregnant rat placenta. Sephadex G-100 gel-filtration analysis of mid-pregnant rat serum and placentas revealed a broad elution profile of PL activity $[1,13]$, which we separated into two substances by high-performance liquid chromatography gelfiltration [14, 15]. Thus, the PL activity in midpregnant serum does not depend upon a single molecular type, but involves at least two molecular types, PL-I (molecular mass $45-50 \mathrm{kDa}$ ) and PL- $\alpha$ (55-60 kDa) $[14,15]$. These PLs were demonstrated to be $\mathrm{N}$-glycosylated proteins, as they were sensitive to several glycosidases [14, 15].

PRL, GH and PLs appear to have evolved from a single ancestral gene by gene-duplication and sequence divergence [16]. All the rat PLs found so far, with the exception of PL-II, have one or two putative N-glycosylation sites [7-12, 17], and the molecular evolution of the glycoresidues is also a matter of interest. 
In this paper, we describe a novel PL (PL-Im) cDNA, which is expressed specifically during midpregnancy in the rat placenta. The structure of PLIm cDNA is of particular interest, as its nucleotide sequence is a mosaic of mid-pregnant and latepregnant PLs (PL-I and PL-Iv respectively) and has no particular sequence of its own.

\section{Materials and Methods}

\section{Reagents}

pBluescript and $\lambda \mathrm{ZAP}$ were purchased from Stratagene (California, USA). Oligotex dT30, AmpliTaq ${ }^{\mathrm{TM}}$ polymerase, ligase, T4 polynucleotide kinase and pUC119 were from Takara Shuzo (Kyoto, Japan). The restriction endonucleases, AMV reverse transcriptase, random primer labeling kit and hybridization blocking reagent were from Boehringer Mannheim Yamanouchi (Tokyo, Japan). Agarose and the AutoRead sequencing kit were from Pharmacia LKB (Uppsala, Sweden). [ $\left.{ }^{32} \mathrm{P}\right] \mathrm{dCTP}(3000 \mathrm{Ci} / \mathrm{mmol})$ was from New England Nuclear (Boston, USA), and all the other reagents were from Wako Pure Chemicals (Osaka, Japan).

\section{Animal treatments and tissue preparation}

Adult Wistar (Imamichi Institute for Animal Reproduction, Ibaraki, Japan) and Sprague-Dawley (Clea Japan, Inc. Tokyo, Japan) rats were kept under a lighting schedule of $14 \mathrm{~h}$ light (lights on 0500 h) and $10 \mathrm{~h}$ dark (lights off $1900 \mathrm{~h}$ ) and allowed food and water ad libitum. Wistar strain rats were used, unless stated otherwise. During the evening of the proestrus day, each female was housed with a male, and the day that sperm were observed in a vaginal smear was designated as day 0 of pregnancy. The placental tissues remaining after removal of the embryos with forceps were collected every 2 days from days 10 to 20 inclusive, frozen quickly and stored at $-80^{\circ} \mathrm{C}$ until required for RNA extraction.

Note. The novel nucleotide sequence data published here have been deposited with the DDBJ, EMBL and GenBank Nucleotide Sequence Databases and are available under the accession number D21103.

\section{Extraction of RNA}

The total RNAs were isolated from the placentas obtained on days $10,12,14,16,18$ and 20 of pregnancy using the CsCl-ultracentrifuge method [18], and the RNAs isolated on each day were subjected to Northern blot analysis. The poly(A) RNAs of days 10 and 12 were selected with Oligotex dT30, as described elsewhere [19], and were used in the synthesis of first-strand cDNA for Polymerase chain reaction $(P C R)$ and construction of a $\lambda Z A P$ cDNA library.

\section{Preparation of probe for screening the cDNA library}

Two pairs of PCR primers, H- and F-primers, based on the nucleotide sequences of rat PL family members, were designed (Fig. 1A) and synthesized using an Oligo 1000 DNA Synthesizer (Beckman Instruments, Inc. California, USA) [18]. The firststrand cDNA used for the PCR was transcribed from the poly(A) RNA with AMV reverse transcriptase [20], and PCR amplification was carried out in a final reaction volume of $100 \mu l$ containing the cDNA, $20 \mathrm{mM}$ Tris- $\mathrm{HCl}$ (pH 8.8), $10 \mathrm{mM} \mathrm{KCl}, 6$ $\mathrm{mM}\left(\mathrm{NH}_{4}\right)_{2} \mathrm{SO}_{4}, 1.5 \mathrm{mM} \mathrm{MgCl}, 0.1 \%$ Triton X-100, $200 \mathrm{mM}$ dNTP, $1.0 \mathrm{mM}$ each PCR primer and 2.5 units of AmpliTaq ${ }^{\mathrm{TM}}$ polymerase. The reaction was carried out in a Quick Thermo (Nippon Genetics, Tokyo, Japan) and involved 30 cycles of denaturation $\left(94^{\circ} \mathrm{C}\right.$ for $\left.1 \mathrm{~min}\right)$, annealing $\left(45^{\circ} \mathrm{C}\right.$ for $\left.1 \mathrm{~min}\right)$ and extension $\left(72^{\circ} \mathrm{C}\right.$ for $\left.2 \mathrm{~min}\right)$ [21]. The PCR products were analyzed by electrophoresis on $1.0 \%$ agarose gel in TAE (40 mM Tris-acetate containing 1 mM EDTA).

The amplified PCR products were ligated into a pUC119 vector cut by SmaI and then transformed in Escherichia coli strain XL1-blue. After analysis of the nucleotide sequence [18], a novel cDNA (690 bp), shown in Fig. 2, was found and designated F12.

\section{DNA sequencing and sequence analysis}

The DNA sequence was obtained on both strands of DNA by the dideoxy-chain-termination method with an AutoRead sequencing kit and an A.L.F. DNA sequencer (Pharmacia LKB, Uppsala, Sweden) [22]. Sequence analysis was carried out using MacMollyTetra computer software (Soft Gene, Berlin, Germany). 


\section{Construction and screening of the cDNA library}

The F12 was labeled with [ $\left.{ }^{32} \mathrm{P}\right]-\mathrm{dCTP}$ using random primers [23] and used as a probe to screen the cDNA library in $\lambda Z A P$, which was constructed from placental poly(A) RNA obtained on day 12 of pregnancy [18]. Approximately, $1.2 \times 10^{5}$ plaques of the library were plated and transferred to nylon filters, Hybond-N (Amersham, Tokyo, Japan). They were then hybridized with the probe for $24 \mathrm{~h}$ at $42^{\circ} \mathrm{C}$ in $5 \times$ SSC which contained $0.02 \%$ SDS, $0.1 \%$ lauroylsarcosine and $1 \%$ blocking reagent, washed with $1 \times \mathrm{SSC} / 0.1 \% \mathrm{SDS}$ at $25^{\circ} \mathrm{C}$ for $10 \mathrm{~min}$ and then with $0.2 \times \mathrm{SSC} / 0.1 \%$ SDS at $60^{\circ} \mathrm{C}$ for 10 min, after which X-ray film was exposed to the filters at $-80^{\circ} \mathrm{C}$ for $24 \mathrm{~h}$. The phagemid-selected plaque was transformed in XL1-blue [18].

\section{Northern blot analysis}

The total RNA (40 $\mu \mathrm{g})$, dissolved in electrophoresis buffer ( $20 \mathrm{mM}$ MOPS (pH 7.0), $5 \mathrm{mM}$ sodium acetate and $1 \mathrm{mM}$ EDTA) containing 50\% formamide and $6.5 \%$ formaldehyde, was heated to $65^{\circ} \mathrm{C}$ for $15 \mathrm{~min}$, electrophoresed on $1.0 \%$ agarose/ formamide gel and transferred to a nylon membrane, Hybond-N (Amersham, Tokyo, Japan) [18]. The membrane was hybridized with the [ $\left.{ }^{32} \mathrm{P}\right]-l a-$ beled F12 in $5 \times$ SSC containing $50 \%$ formamide, $0.02 \%$ SDS, $0.1 \%$ lauroylsarcosine and $1 \%$ blocking reagent, then washed with $1 \times \mathrm{SSC} / 0.1 \%$ SDS at $25^{\circ} \mathrm{C}$ for $20 \mathrm{~min}$ followed by $0.2 \times \mathrm{SSC} / 0.1 \% \mathrm{SDS}$ at $60^{\circ} \mathrm{C}$ for $10 \mathrm{~min}$, after which $\mathrm{X}$-ray film was ex-

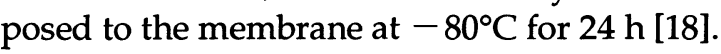

\section{Southern blot analysis}

Genomic DNA (10 $\mu \mathrm{g})$ isolated from the livers of Wistar and Sprague-Dawley male rats was digested with BamHI, HindIII or EcoRI and electrophoresed on $0.8 \%$ agarose gel in TAE [18]. They were then transferred to nylon membranes, Hybond-N, and hybridized with the [ $\left.{ }^{32} \mathrm{P}\right]$-labeled F12 in $5 \times$ SSC containing $50 \%$ formamide, $0.02 \%$ SDS, $0.1 \%$ lauroylsarcosine and 5\% blocking reagent. Then, each membrane was washed twice with $1 \times \mathrm{SSC} / 0.1 \% \mathrm{SDS}$ at $25^{\circ} \mathrm{C}$ for $10 \mathrm{~min}$ each, followed by four washes with $0.2 \times \mathrm{SSC} / 0.1 \%$ SDS at $60^{\circ} \mathrm{C}$ for $30 \mathrm{~min}$ each, and $\mathrm{X}$-ray film was exposed to the membranes at $-80^{\circ} \mathrm{C}$ for $24 \mathrm{~h} \mathrm{[18]}$.

\section{Results}

\section{Amplification of a novel PL $m R N A$ by the PCR}

The results of the PCR using the H- and F-primers are shown in Fig. 1B. The $596 \mathrm{bp}$ product in both cDNA preparations (days 10 and 12) was amplified by the H-primers, and the corresponding $690 \mathrm{bp}$ bands were amplified by the F-primers. Sequence analysis showed that these bands contained several PLs including PL-II. We found that the sequence of one of the DNA bands $(596 \mathrm{bp}$, H12) amplified by the H-primers was a novel one. Another DNA band amplified by the F-primers (690 bp, F12) contained H12. Interestingly, the nucleotide sequence of F12 was very similar, but not identical, to those of PL-I [7], PL-Iv [9], PL-II [8], PLP-A [10], PLP-B [11] and PLP-C [12].

\section{Cloning of novel PL cDNA (PL-Im) by Screening the $\lambda Z A P$ CDNA library}

A cDNA library of $1.2 \times 10^{6}$ recombinants was constructed from the mRNA obtained on day 12 of pregnancy. After the second screening, a clone (pE01-a) was obtained and its nucleotide sequence was determined (Fig. 2). The sequence contained an open reading frame of $687 \mathrm{bp}$ encoding 229 amino acids. There were two potential glycosylation sites, Asn-Val-Ser at position 108-110 and Asn-Arg-Thr at position 157-159. Cleavage of the signal peptide sequence would be expected to occur between Ser and Lys at position 29-30. The polyadenylation signal and poly(A) tail were contained in $130 \mathrm{bp}$ of the $3^{\prime}$-untranslated region, although the 5'-non-coding region was truncated. The protein encoded by the insertion of $\mathrm{pE01-a}$ was designated PL-I mosaic (PL-Im) from its structure, as described in the Discussion.

\section{Northern blot analysis of the rat placental PL-Im}

The expression of PL-Im mRNA in the rat placenta was investigated using Northern blot analysis (Fig. 3A). Intense mRNA bands of approximately $1.0 \mathrm{~kb}$ were detected in the placentas obtained during mid-pregnancy (days 10 and 12), whereas this expression was not evident on the other days. The amounts of RNA obtained on days 10 to 20 inclusive subjected to analysis were almost 

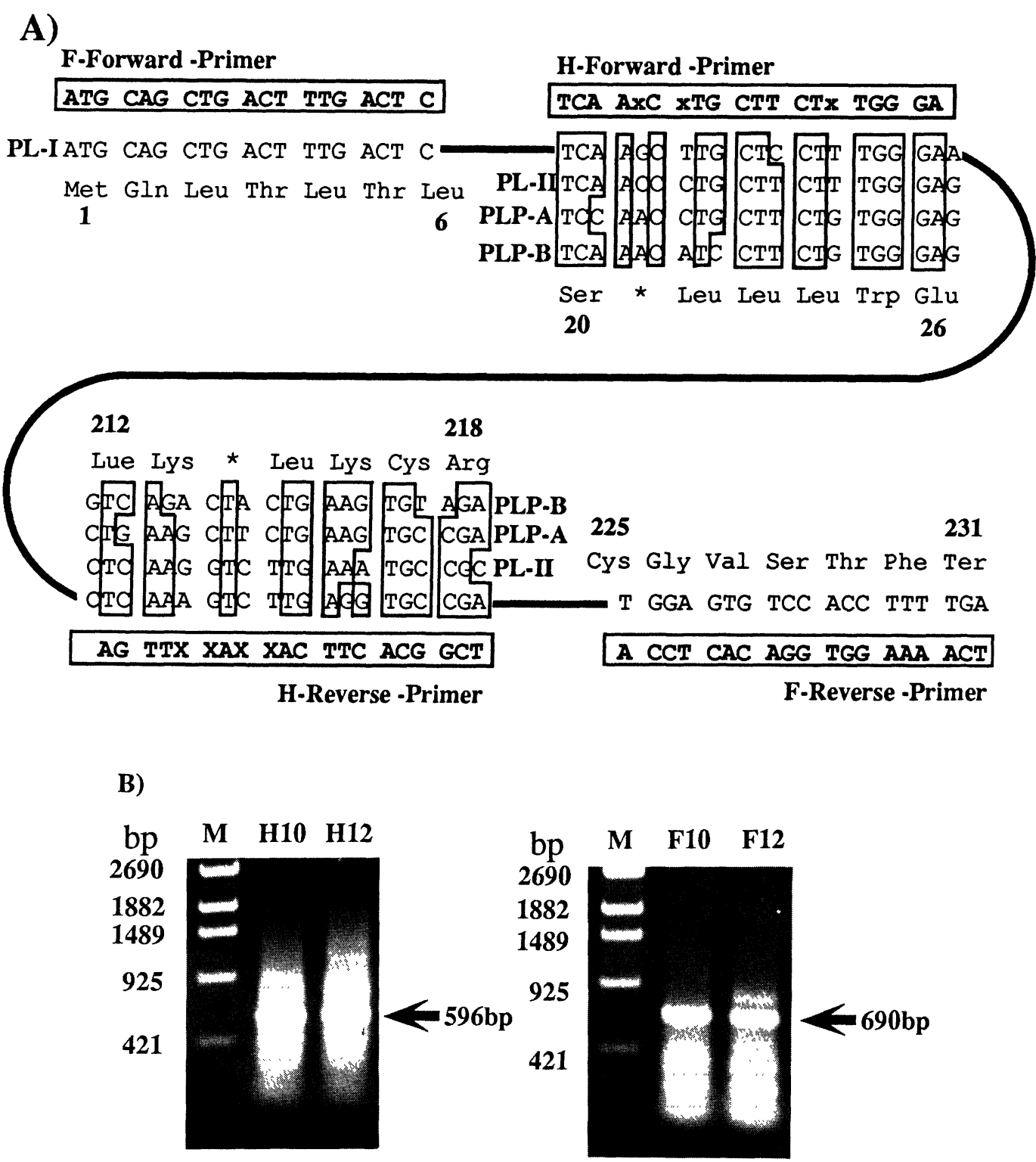

Fig. 1. PCR Amplification of the PL mRNAs expressed during mid-pregnancy. A) H-primers (mixed primers), based on the highly homologous parts of the nucleotide sequences of PL-I, PL-II, PLP-A and PLP-B, and F-primers containing the initiation and stop codons of PL-I were designed. The amino acids are numbered according to the PL-I. B) These primers were used to investigate mRNA expression in the placenta at mid-pregnancy by PCR. After analysis of the PCR products by $1.0 \%$ agarose electrophoresis, they were stained with ethidium bromide. The major fragments obtained, comprised of $596 \mathrm{bp}$ (H-primers) and $690 \mathrm{bp}$ (F-primers), were amplified (M, marker ( $\lambda$ EcoT14I digest); H10, PCR product using $\mathrm{H}$-primer and cDNA from day 10; H12, H-primer and cDNA from day 12; F10, F-primer and cDNA from day 10; F12, F-primer and cDNA from day 12).

equal judged by the intensity of the samples stained with ethidium bromide (Fig. 3B).

\section{Genomic DNA restriction enzyme patterns of PL-Im}

The Southern blot results are shown in Fig. 4.
When the genomic DNA from Wistar and Sprague-Dawley strain rats was pretreated with EcoRI, four bands were detected, including a $0.9 \mathrm{~kb}$ fragment. A single broad band was produced after HindIII and BamHI treatment of both strains. 
Met Gln Leu Thr Leu Thr Leu Ser Gly Ser Gly Met Gln Leu Leu Leu Leu Val PL-Im ATG CAG CTG ACT TTG ACT CTT TCG GGC TCT GGT ATG CAA CTG TTG CTG CTG GTG $\begin{array}{llrr}27 & 36 & 45 & 54\end{array}$

Ser Ser Leu Leu Leu Trp Glu Asn Val Ala Ser Lys Pro Thr Ala Ile Val Ser Thr Asp TCA AGC TTG CTC CTT TGG GAA AAC GTG GCC TCC AAA CCA ACT GCC ATT GTG TCC ACT GAT $8 1 \longdiv { 9 0 } \quad 9 9 \quad 1 0 8$

Asp Leu Tyr His Arg Leu Val Glu Gln Ser His Asn Thr Phe Ile Met Ala Ala Asp Val GAC CTA TAT CAT CGT TTG GTT GAA CAG TCT CAT AAT ACA TTT ATC ATG GCT GCA GAT GTA
123
132
141
150
159
168

Tyr Arg Glu Phe Asp Ile Asn Phe Ala Lys Arg Ser Trp Met Lys Asp Arg Ile Leu Pro TAC CGT GAA TTT GAT ATA AAT TTT GCC AAG AGA AGT TGG ATG AAA GAC AGG ATA CTT CCC $\begin{array}{llllll}183 & 192 & 201 & 210 & 219 & 228\end{array}$

Leu Cys His Thr Ala Ser Ile His Thr Pro Glu Asn Leu Glu Glu Val His Glu Met Lys CTG TGT CAC ACT GCT TCC ATC CAT ACT CCA GAG AAT CTA GAG GAA GTC CAT GAA ATG AAA $\begin{array}{llllll}243 & 252 & 261 & 270 & 279 & 288\end{array}$

Thr Glu Asp Phe Leu Asn Ser Ile Ile Asn Val Ser Val Ser Trp Lys Glu Pro Leu Lys ACT GAA GAC TTC CTG AAC TCA ATC ATC AAT GTT TCA GTT TCC TGG AAA GAA CCT CTG AAA $\begin{array}{llllll}303 & 312 & 321 & 330 & 339 & 348\end{array}$

His Leu Val Ser Ala Val Thr Asp Leu Pro Gly Ala Ser Val Ser Met Gly Lys Lys Ala CAC TTG GTG TCT GCA GTG ACT GAT CTT CCG GGA GCT TCT GTT AGT ATG GGG AAA AAA GCT $\begin{array}{llllll}363 & 372 & 381 & 390 & 399 & 408\end{array}$

Val Asp Met Lys Asp Lys Asn Leu Ile Ile Leu Glu Gly Leu Gln Thr Leu Tyr Asn Arg GTT GAT ATG AAG GAC AAA AAT CTT ATA ATT CTG GAG GGA CTT CAG ACC TTA TAC AAC AGG $\begin{array}{llllll}423 & 432 & 441 & 450 & 459 & 468\end{array}$

Thr Gln Ala Lys Val Glu Glu Asn Phe Glu Asn Phe Asp Tyr Pro Ala Trp Ser Gly Leu ACT CAG GCT AAA GTT GAA GAA AAT TTT GAA AAT TTT GAC TAC CCT GCC TGG TCT GGA CTC $\begin{array}{llllll}483 & 492 & 501 & 510 & 519 & 528\end{array}$

Lys Asp Leu Gln Ser Ser Asp Glu Asp Thr His Leu Phe Ala Ile Tyr Asn Leu Cys Arg AAA GAC TTG CAG TCA TCT GAT GAA GAC ACT CAT CTT TTT GCC ATT TAT AAC CTG TGC CGC $\begin{array}{llllll}543 & 552 & 561 & 570 & 579 & 588\end{array}$

Cys Phe Lys Arg Asp Ile His Lys Ile Asp Thr Tyr Leu Lys Val Leu Arg Cys Arg Val TGC TTT AAA AGG GAC ATC CAT AAG ATT GAC ACT TAT_CTC AAA GTC TTG AGG TGC CGA GTT $603 \quad 612 \quad 621$

Val Phe Lys Asn Glu Cys Gly Val Ser Thr Phe TER

GTC TTT AAG AAT GAG TGT GGA GTG TCC ACC TTT TGA AGTCTTGCACCCAATGTTGAACCAGACTTTT 663

GTAATGCTTTTTCGCCTCTCGGTGTATTCAGAGCTGTAATGGAATTCTTTTCATAAAATAAAATGGAATTATTTAGAAA

\section{AAAAAAAAAAAAAAAAA}

Fig. 2. Nucleotide and deduced amino acid sequences of PL-Im cDNA. The PL-Im cDNA was cloned by screening the $\lambda Z A P$ cDNA library constructed from placenta obtained during mid-pregnancy (day 12). Its nucleotide sequence was determined and the amino acid sequence of PL-Im was deduced. The PL-Im cDNA contains an open reading frame with $687 \mathrm{bp}$ nucleotides encoding 229 amino acids. The nucleotides and amino acids were numbered from the initiation codon, ATG. The position of the signal cleavage site was predicted according to its homology with other members of the PL family $[7,29]$, and is marked with an arrow. The positions of the two potential glycosylation sites, Asn-Val-Ser at position 108-110 and Asn-Arg-Thr at position 157-159, are shown enclosed in boxes, and the nucleotides corresponding to the $\mathrm{H}$ - and $\mathrm{F}$-primers are underlined. The nucleotide sequences of $\mathrm{H} 12$ and F12 correspond to these parts of PL-Im. 
A)

\section{Day of Pregnancy}

\section{$\begin{array}{llllll}10 & 12 & 14 & 16 & 18 & 20\end{array}$}

\section{$28 S$}

$18 S$

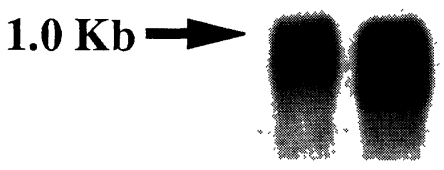

B)

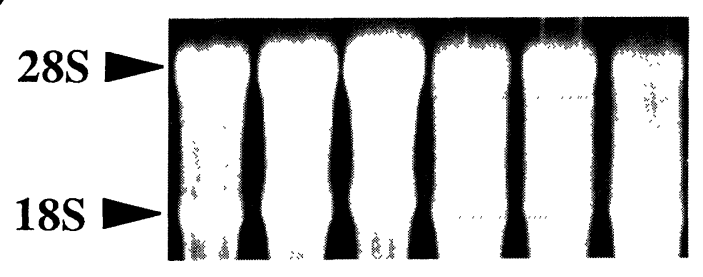

Fig. 3. Northern blot analysis of rat placental PL-Im. A) Total RNA preparations ( $40 \mu \mathrm{g}$ each) extracted from placentas obtained on days $10,12,14,16,18$ and 20 of pregnancy were electrophoresed on $1.0 \%$ agarose/formamide gel and transferred to a nylon membrane, which was hybridized with [ $\left.{ }^{32} \mathrm{P}\right]$-labeled F12. The mobilities of $28 \mathrm{~S}$ and $18 \mathrm{~S}$ are shown on the left side and the arrow indicates $1.0 \mathrm{~kb}$ PL-Im mRNA. B) After electrophoresis, the samples were stained with ethidium bromide.

A)

B)
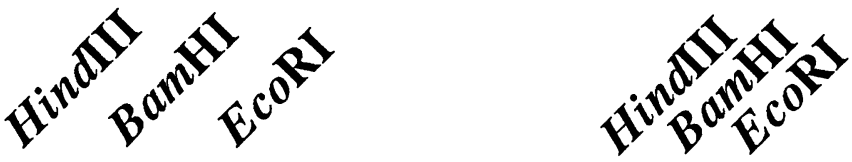

$\mathbf{K b}$

7.7-

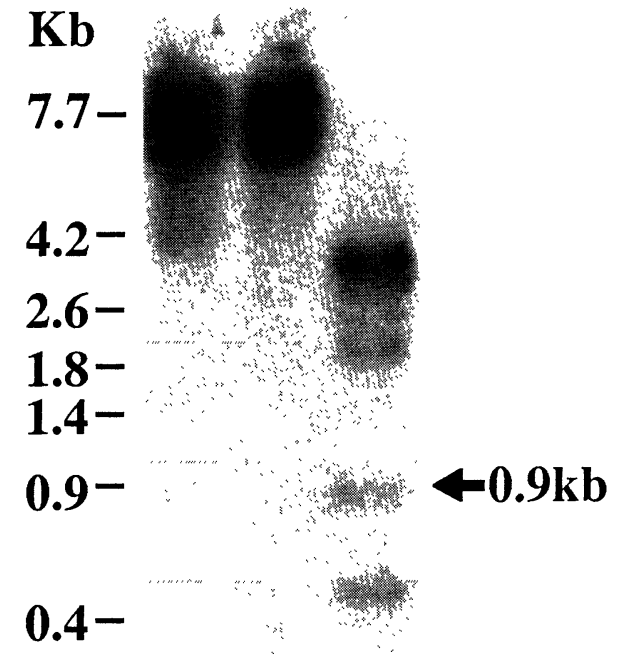

$\mathbf{K b}$

Wistar

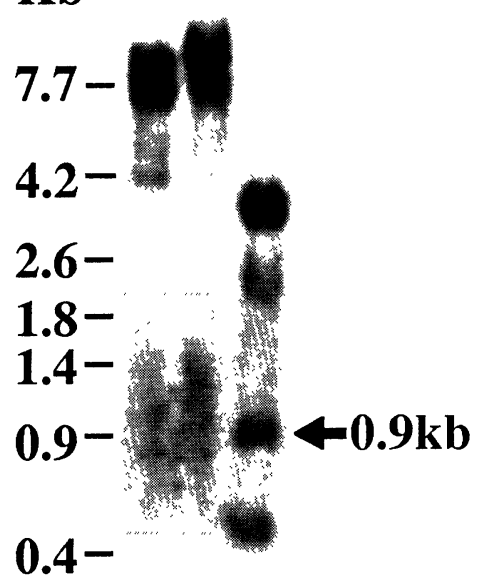

\section{SD}

Fig. 4. Southern blot analysis of rat genomic DNA with PL-Im cDNA. Genomic DNA preparations (10 $\mu$ g each) of Wistar A) or of Sprague-Dawley B) rat strains were treated with a restriction enzyme, EcoRI, HindIII or BamHI, electrophoresed on $0.8 \%$ agarose gel and transferred to a nylon membrane, which was hybridized with [ $\left.{ }^{32} \mathrm{P}\right]$-labeled F12. The arrow $(0.9 \mathrm{~kb})$ indicates the original band detected with the PL-Im probe. 


\section{Discussion}

We have successfully cloned a cDNA encoding a novel PL, PL-Im, from the rat placenta obtained during mid-pregnancy and determined its nucleotide sequence. The particularly interesting point to note is its structure and time of expression; PLIm cDNA has a mosaic structure of PL-I (midpregnancy-specific) and PL-Iv (late-pregnancyspecific) and is expressed specifically during midpregnancy.

On the basis of its high homology with the 6 members of the rat PL family (PL-I, PL-Iv, PL-II, PLP-A, PLP-B and PLP-C), PL-Im is a new member of the PL family [7-12] (Fig. 5). In particular, PL-Im cDNA is highly homologous (over $90 \%$ ) with PL-I and PL-Iv and, furthermore, detailed comparisons of these nucleotide sequences revealed that PL-Im cDNA does not possess its own sequence but is a mosaic structure of PL-I (mid-pregnancy-specific) and PL-Iv (late-pregnancy-specific) (Fig. 6).

The PL-Im contains the 20 amino acids which are conserved in these 6 other PLs. The positions of these 20 amino acids are; Cys (80, 199, 216 and 224), Leu (14, 16, 23, 103, 181, 196 and 214), Ser (19, 29 and 183), Trp (24 and 175), Glu (25), His (119), Asp (203) and Arg (217) [7-12]. Of these, the four Cys residues, which are considered to be parts of the disulfide bonds that determine the tertiary structure of proteins $[24,25]$, are conserved in the rat PL family without exception. In addition, three other amino acids, Arg at 43 and 202 and Lys at 212 in PL-Im, have also been postulated to be essential for reactions with the lactogenic hormone receptor in a study of point mutation in mouse PLs $[26,27]$.

Northern blot analysis revealed that PL-Im mRNA was strongly expressed in the rat placenta on days 10 and 12, and this abundance of PL-Im mRNA seems to be similar to that of PL-I and PLIv reported by Robertson [9]. In the present experiment, the sequence of the cDNA used as a probe was more than $90 \%$ homologous with PL-I mRNA, like PL-Iv mRNA. Therefore, it is predicted that the faintly detectable band on day 16 represents cross-hybridization of PL-Iv mRNA. As PL-I and PL-Iv mRNA have much the same level of homology as the probe, it would be expected that the cross-hybridization of PL-I mRNA on days 10 and 12 would be as low as that of PL-Iv mRNA on day 16. Judging from the above, it appears that PL-Im mRNA expressed in mid-pregnant placenta can be detected with this degree of stringency.

Previously, we reported that there were at least two distinct PL-like substances in mid-pregnant rat serum, PL-I and PL- $\alpha$ (molecular masses of 45-50 and 55-60 kDa respectively) [14, 15], although the structure of PL- $\alpha$ has not been determined. PL- $\alpha$ was recognized preferentially by antiserum AII-86,

Homology for Identical Nucleotides (\%)

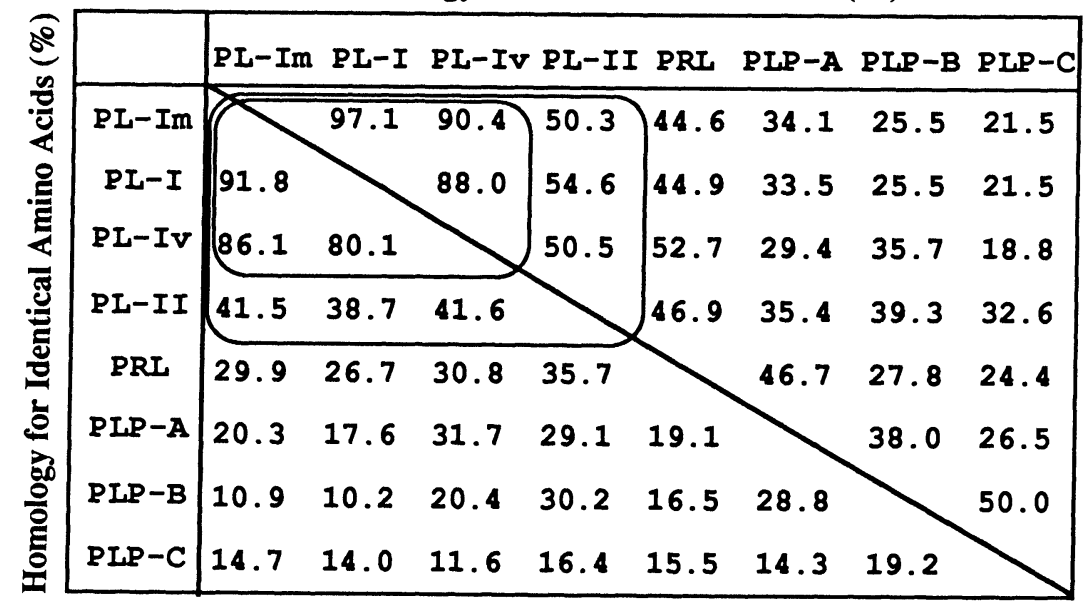

Fig. 5. Homology of PL-Im with the rat PL family. The percentage homologies with identical amino acids and nucleotides are shown. The deduced amino acid and nucleotide sequences of PL-Im are compared with those of PL-I [7, 29], PL-II [8], PL-Iv [9], PLP-A [10], PLP-B [11] and PLP-C [12]. 


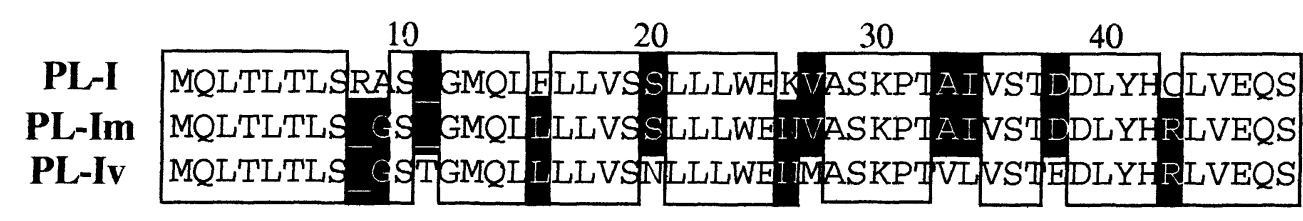

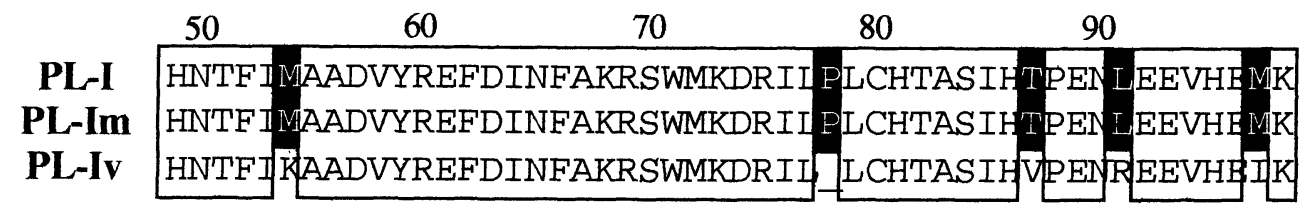
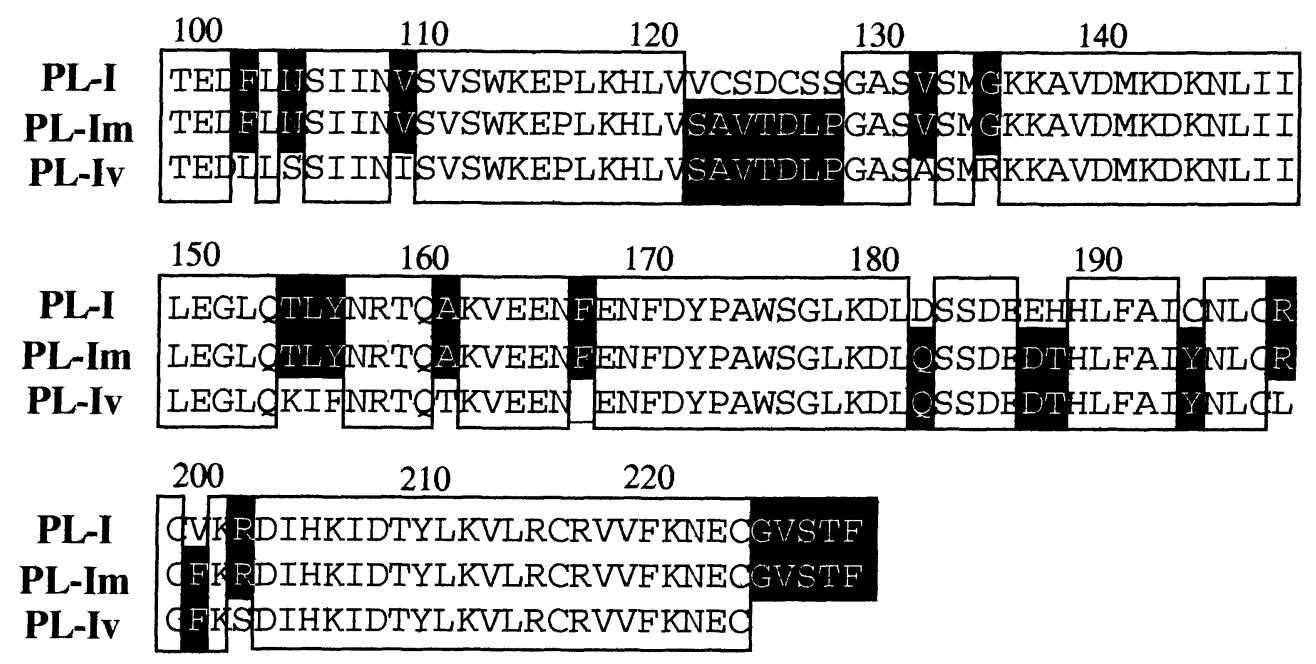

Fig. 6. Comparison of the amino acid structure of PL-Im with those of PL-I and PL-Iv. The nucleotide and deduced amino acid sequences of PL-Im showed it had a mosaic structure of PL-I and PL-Iv and did not possess its own sequence $[7,9]$.

which was specific to the hydrophilic region of PLII, and the recognition site of the PL- $\alpha$ core protein appeared to be analogous to PL-II rather than to PL-I [28]. As the deduced amino acid sequence of PL-Im that corresponds to the antibody recognition site was identical of PL-I, PL-Im should be distinct from PL- $\alpha$.

From the homology of PL-Im with other rat PL family members, we expected that PL-Im would have a signal peptide cleavage site between Ser at position 29 and Lys at position 30 [7, 29]. As PL-Im has two putative glycosylation sites, it may be a secretory glycoprotein, like PL-I, PL-Iv and PL- $\alpha$ $[7,9,14,30]$. The amino acid sequence near the glycosylation site is believed to contain information that determines the final structure of the glycoresidue. Recently, the amino acid sequence motif, Pro-Leu-Arg, which is located in 6-9 residues on the amino-terminal side of the $\mathrm{N}$ glycosylation sites on the hCG $\alpha$ and $\beta$ subunits, was reported to be essential for recognition by $\mathrm{N}$ - acetylgalactosamine-transferase [31]. Although this motif is not included in the PL family, study of the glycoresidue structure(s) is of great interest in this context. The affinities of the PL-I and PL-Iv glycoresidues for concanavalin A differ [30]. The structure near the glycosylation sites of PL-Im is a mosaic of PL-I and PL-Iv. Therefore, structural analysis of the glycoresidues of these PLs will yield new information about modification of protein by glycosylation, and this would be worth studying in detail.

When subjected to Southern blot analysis, similar and simple hybridization patterns were obtained for both the genomic DNA preparations from the two strain rats, Wistar and SpragueDawley, which suggests there is no polymorphism in the PL-Im gene area. However, digestion of PLIm with EcoRI yielded a PL-Im-specific fragment $(0.9 \mathrm{~kb})$, which was not present after Southern blot analysis of PL-I and PL-Iv [9]. Therefore, the restriction enzyme pattern of PL-Im differed dis- 
tinctly from those of these PLs. In view of the previous report that PL-I and PL-Iv were independent of each other in the encoded area on the gene, these very similar PLs (PL-I, PL-Iv and PL-Im) appear not to be produced in the same genomic area by alternative splicing, but to be encoded in different genomic areas.

The possible molecular evolution process was deduced by constructing a dendrogram based on the nucleotide sequence homologies of PL family members (Fig. 7). The mid-pregnancy-specific PLs (PL-Im and PL-I) appear to be derived from the late-pregnancy-specific PLs, and PL-Im is located between PL-Iv and PL-I in the process of their molecular evolution. Furthermore, as shown in Table 1 , the replacement to silent substitute ratio of PL-Iv to PL-Im is $1.21(54.8 \% / 45.2 \%)$, whereas that of PLIm to PL-I is quite high $(3.50,77.8 \% / 22.2 \%)$. Therefore, it is likely that positive selective influences have caused rapid fixation of replacement substitutes in the genes.

The rat has a very efficient reproductive system, which utilizes PRL as a luteotrophic factor [32]. The rat has no luteal phase during its normal ovulatory cycle and ovulates at 4-5 day intervals if the female does not have a chance to mate with a male. The PRL surges following mating, which is induced by cervical stimulation, is necessary to initiate and maintain the progesterone secretion function of the corpus luteum. PL is a primary candidate for the luteotrophic factor of gestation, in view of the observations that PRL secretion ceases at mid-pregnancy following the initiation of PL secretion [33] and PLs are able to bind to the ovarian PRL receptor [14, 15, 28]. Mid-pregnancy-specific PLs appear to be peculiar to the rat, mouse and hamster [7, 17], while PL expression occurs predominantly during late pregnancy in other species. Therefore, acquiring mid-pregnancy PLs, especially those involved in the evolutionary process from PL-Im to PL-I, may lead to an efficient reproductive strategy for these species.

\section{Acknowledgements}

We gratefully acknowledge Dr. D. B. Douglas for proofreading the manuscript. This work was supported, in part, by a grant from the Ministry of Education, Science and Culture, Japan.

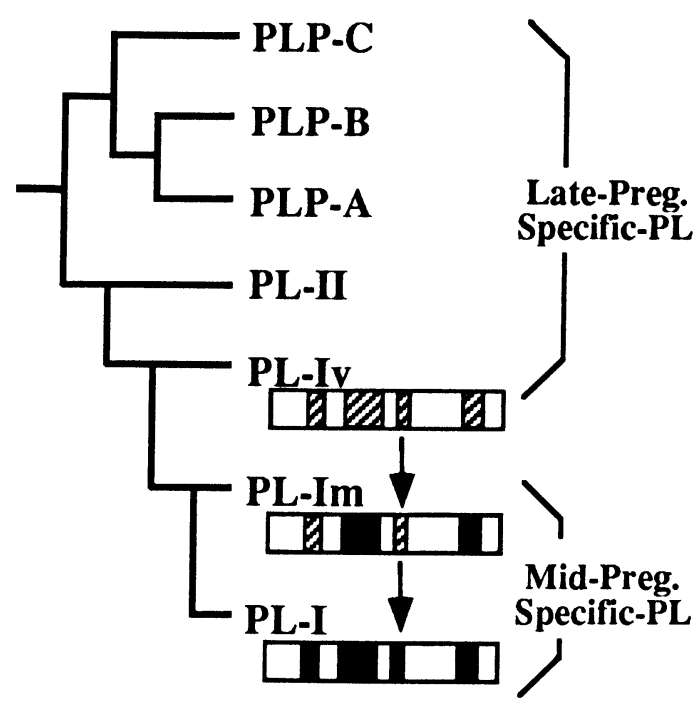

Fig. 7. Dendrogram of the PL family. The dendrogram was constructed according to the nucleotide sequence homologies of 7 members of the PL family: PL-Im, PL-I, PL-Iv, PL-II, PLP-A, PLP-B and PLP-C.

Table 1. Codon-by-codon comparisons of PL-Im, PL-I and PL-Iv

\begin{tabular}{rccc}
\hline Comparison & Identical codon & \multicolumn{2}{c}{ Codons differing by one base } \\
\hline & & Silent & Replacement \\
\cline { 2 - 3 } PL-Iv vs. PL-Im & $84.2 \%$ & $45.2 \%$ & $54.8 \%$ \\
& $(187 / 222)$ & $(14 / 31)$ & $(17 / 31)$ \\
PL- Im vs. PL-I & $95.5 \%$ & $22.2 \%$ & $77.8 \%$ \\
& $(210 / 220)$ & $(2 / 9)$ & $(7 / 9)$ \\
\hline
\end{tabular}

When nucleotide sequences are compared codon by codon, there can be two types of codon that differ by one base. One is the replacement substitute (one base change in a codon results in an amino acid replacement), and the other is the silent substitute (one base change does not affect an amino acid, but codes a synonymous amino acid ). The percentage of identical, silent and replacement substituted codons among PL-Im, PL-I and PL-Iv are shown. 


\section{References}

1. Robertson MC, Friesen HG (1981) Two forms of rat placental lactogen revealed by radioimmunoassay. Endocrinology 108: 2388-2390.

2. Colosi P, Marr G, Lopez J, Haro L, Ogren L, Talamantes F (1982) Isolation, purification, and characterization of mouse placental lactogen. Proc Natl Acad Sci USA 79: 771-775.

3. Bolander FF, Fellows RE (1976) Purification and characterization of bovine placental lactogen. J Biol Chem 251: 2703-2708.

4. Martal J, Djiane J (1975) Purification of a lactogenic hormone in sheep placenta. Biochem Biophys Res Commun 65: 770-778.

5. Shome B, Friesen HG (1971) Purification and characterization of monkey placental lactogen. Endocrinology 89: 631-641.

6. Turtle JR, Beck P, Daughaday WH (1966) Purification of human placental lactogen. Endocrinology 79: 187-190.

7. Robertson MC, Croze F, Schroedter IC, Friesen HG (1990) Molecular cloning and expression of rat placental lactogen-I complementary deoxyribonucleic acid. Endocrinology 127: 702-710.

8. Duckworth ML, Kirk KL, Friesen HG (1986) Isolation and identification of a cDNA clone of rat placental lactogen II. J Biol Chem 261: 10871-10878.

9. Robertson MC, Schroedter IC, Friesen HG (1991) Molecular cloning and expression of rat placental lactogen, a variant of rPL-I present in late pregnant rat placenta. Endocrinology 129: 2746-2756.

10. Duckworth ML, Peden LM, Friesen HG (1986) Isolation of a novel prolactin-like cDNA clone from developing rat placenta. J Biol Chem 261:1087910884.

11. Duckworth ML, Oeden LM, Friesen HG (1988) A third prolactin-like protein expressed by the developing rat placenta: complementary deoxyribonucleic acid sequence and partial structure of the gene. Mol Endocrinol 2: 912-920.

12. Deb S, Roby KF, Faria TN, Szpirer CG, Levan C, Kwok SCM, Soares MJ (1991) Molecular cloning and characterization of prolactin-like protein $C$ complementary deoxyribonucleic acid. J Biol Chem 266: 23027-23032.

13. Robertson MC, Friesen HG (1975) The purification and characterization of rat placental lactogen. Endocrinology 97: 621-629.

14. Furuyama N, Shiota K, Takahashi M (1991) Two distinct placental lactogen-like substances in serum during mid-pregnancy in the rat. Endocrinol Japon 38: 533-540.

15. Shiota K, Furuyama N, Takahashi M (1991) Placental lactogen secretion during prolonged-pregnancy in the rat: the ovary plays a pivotal role in the control of placental function. Endocrinol Japon 38: 541549.

16. Wallis M (1981) The molecular evolution of pituitary growth hormone prolactin and placental lactogen: a protein family showing variable rates of evolution. J Mol Evol 17: 10-18.

17. Colosi P, Talamantes F, Linzer DIH (1987) Molecular cloning and expression of mouse placental lactogen I complementary deoxyribonucleic acid. Mol Endocrinol 1:767-776.

18. Sambrook J, Fritsch EF, Maniatis T (1989) Molecular Cloning; A Laboratory Manual, 2nd ed. Cold Spring Harbor Press, Cold Spring Harbor, New York.

19. Kuribayashi K, Hikata M, Hiraoka O, Miyamoto C, Furuichi Y (1988) A rapid and efficient purification of poly(A)-mRNA by oligo(dT)-Latex. Nucleic Acids Res 19: 61-64.

20. Gubler U, Hofman BJ (1983) A simple and very efficient method for generating cDNA libraries. Gene 25: 263-269.

21. Saiki RK, Scharf S, Faloona F, Mullis KB, Horn GT, Erlrich HA, Arnhein N (1985) Enzymatic amplification site analysis for diagnosis of sickle cell anemia. Science 230: 1350-1354.

22. Sanger F, Nicklen S, Coulson AR (1977) DNA sequencing with chain-termination inhibitors. Proc Natl Acad Sci USA 74: 5463-5467.

23. Feinberg AP, Vogelstein B (1983) A technique radiolabeling DNA restriction endonuclease fragment to high specific activity. Anal Biochem 132: 613.

24. Southard JN, Talamantes F (1991) Placental prolactin-like protein in rodents: variations on a structural theme. Mol Cell Endocrinol 79: C133-C140.

25. Nicoll CS, Mayer GL, Russell SM (1986) Structural features of prolactin and growth hormones that can be related to their biological properties. Endocrine Reviews 7: 169-203.

26. Davis JA, Linzer DIH (1989) A mutant lactogenic hormone binds, but does not activate, the prolactin receptor. Mol Endocrinol 3: 949-948.

27. Davis JA, Linzer DIH (1989) Mutational analysis of a lactogenic hormone reveals a role for lactogenspecific amino acid residues in receptor binding and mitogenic activity. Mol Endocrinol 3: 19871995.

28. Hattori N, Hirosawa M, Wakimasu M, Takahashi M, Shiota K, Ogawa T (1993) Characterization of rat placental lactogen- $\alpha$ (PL- $\alpha$ ) with an antipeptide antibody directed against rat PLs. Endocrine Journal 40: 673-681. 
29. Heijne GV (1983) Patterns of amino acids near single-sequence cleavage sites. Eur J Biochem 133: 17-21.

30. Deb S, Faria TN, Roby KF, Larsen D, Kwok SCM, Talamantes F, Soares MJ (1991) Identification and characterization of a new member of the prolactin family, placental lactogen-I variant. J Biol Chem 266: 1605-1610.

31. Smith PL, Baenziger JU (1992) Molecular basis of recognition by the glycoprotein hormone-specific N-acetylgalactosamine-transferase. Proc Natl Acad
Sci USA 89: 329-333.

32. Morishige WK, Rothchild I (1974) Temporal aspects of the regulation of corpus luteum function by luteinizing hormone, prolactin and placental luteotrophin during the first half of pregnancy in the rat. Endocrinology 95: 260-274.

33. Tonkowicz PA, Voogt JL (1983) Termination of prolactin surges with development of placental lactogen secretion in the pregnant rat. Endocrinology 113: 1314-1318. 